\title{
Experimental study on the effect of in-feed administration of a clinoptilolite-rich tuff on certain biochemical and hematological parameters of growing and fattening pigs
}

\author{
C. Alexopoulos ${ }^{\text {a,* }}$, D.S. Papaioannou ${ }^{\text {a }}$, P. Fortomaris ${ }^{\text {a }}$, C.S. Kyriakis ${ }^{\text {a }}$, \\ A. Tserveni-Goussi ${ }^{\text {a }}$, A. Yannakopoulos ${ }^{\text {a }}$, S.C. Kyriakis ${ }^{b}$ \\ ${ }^{\text {a }}$ Faculty of Veterinary Medicine, Aristotle University of Thessaloniki, 54124 Greece \\ ${ }^{\mathrm{b}}$ Foundation of Biomedical Research, Academy of Athens, 11527 Athens, Greece
}

Received 22 August 2006; received in revised form 15 January 2007; accepted 22 January 2007

\begin{abstract}
The effect of the long-term dietary use of a clinoptilolite-rich tuff $(\mathrm{Cp})$ on certain biochemical and hematological parameters was studied in pigs. Forty-eight healthy piglets (24 females and 24 males) were used in the study, equally allocated in two experimental groups, depending on the inclusion or not of $\mathrm{Cp}$ in their feed $(\mathrm{Cp}+$ and $\mathrm{Cp}-$ groups respectively). $\mathrm{Cp}$ was incorporated in their feed at the inclusion rate of $2 \%$ and was administered continuously from weaning to slaughter. All pigs were individually weighed upon commencement of the study $[25( \pm 3)$ days of age $]$ and subsequently at the end of the weaning, growing and fattening stages $[70( \pm 3), 112( \pm 3)$ and $161( \pm 3)$ days of age, respectively] and blood sample collections were performed for analyses. Cp ingestion was well tolerated and resulted in a higher body weight gain during the weaning stage, as well as during the whole monitoring period $(P<0.05)$. The diet had no effect on serum $\mathrm{K}, \mathrm{Na}, \mathrm{Ca}, \mathrm{P}$, total protein, albumin and total bilirubin concentrations throughout the study $(P>0.05)$. Furthermore, no significant alteration was noticed concerning the hematocrit, leucocyte count and hemoglobin concentration $(P>0.05)$. Conversely, the dietary inclusion of $\mathrm{Cp}$ resulted in a lower serum urea-N and cholesterol concentrations in all blood samplings apart from the initial one $(P<0.05)$. Likewise, $\mathrm{Cp}+$ group demonstrated an elevated serum glucose concentration at the blood samplings performed on 112( \pm 3$)$ and $161( \pm 3)$ days of age and a lower AST activity at the latter $(P<0.05)$. In the context of this study, the long-term dietary use of $\mathrm{Cp}$ at the inclusion rate of $2 \%$ appeared to enhance the performance of growing and fattening pigs without adversely affecting their health status in terms of undesirable changes of their biochemical and hematological profiles.
\end{abstract}

(C) 2007 Elsevier B.V. All rights reserved.

Keywords: Clinoptilolite; Pigs; Serum biochemistry; Hematology

\section{Introduction}

Zeolites are crystalline hydrated aluminosilicates of alkali and alkaline earth cations, consisting of three-

\footnotetext{
* Corresponding author. Tel./fax: +30 310994466.

E-mail address: kalex@vet.auth.gr (C. Alexopoulos).
}

dimensional frameworks of $\mathrm{SiO}_{4}$ and $\mathrm{AlO}_{4}$ tetrahedra linked through the shared oxygen atoms to form an open crystal lattice with approximately uniform pores of molecular dimensions. It is well established that the various applications of these naturally occurring or synthetic materials are based on their physical and chemical properties to act as ion exchangers, catalysts 
and adsorbents [see Mumpton (1999) and references therein].

The dietary use of naturally occurring or synthetic zeolites has been reported to improve feed efficiency, thus leading to a beneficial growth response in pigs (Cool and Willard, 1982; Coffey and Pilkington, 1989; Yannakopoulos et al., 2000), and to alter the blood and/ or tissue mineral concentrations in different species, such as growing pigs (Pond et al., 1988), broilers (Scheideler, 1993) or dairy cows (Enemark et al., 2003). Lately, it has been reported that zeolite-enriched diets affect mineral homeostasis in rats by altering ion transport through the intestinal wall directly (Gerasev et al., 2003a) and renal excretion and re-absorption patterns indirectly (Gerasev et al., 2003b). Furthermore, a decreasing effect of a clinoptilolite containing diet on blood urea-N concentration (Pond and Lee, 1984) and an increasing one on mesenteric blood glucose concentration (Nestorov, 1984) have been reported in growing pigs.

The aforementioned effects may represent the endpoint of respective local and systemic effects in the recipient animal, resulted by the fundamental physicochemical properties of ingested zeolites. More specifically, zeolites exert ion exchange, adsorption and catalytic properties and can display a bufferant behavior in an aqueous solution, altering the gastrointestinal $\mathrm{pH}$ and the ionic composition of the lumen contents and affecting both the mineral uptake and the enzymatic activity of gastrointestinal secretions. Additionally, the well-known affinity of certain zeolites, such as clinoptilolite, for ammonium ions and for several toxic compounds such as $p$-cresol (Shurson et al., 1984) and enterotoxins (Ramu et al., 1997) can favor the physiological status of the intestinal epithelium and thereby influence the digestive and absorption processes. In a long-term basis, whether such physiological changes in the gastrointestinal tract may affect the hematological profiles of the animals as well, cannot be precluded. Interestingly, the evidence provided by previous studies in young pigs (Petkova et al., 1982) and mice (Kartashev and Baskurin, 1995) confirms this hypothesis.

Continuing a previous study dealing with the efficacy of the dietary use of a clinoptilolite-rich tuff (henceforth referred to as $\mathrm{Cp}$ ) in enhancing growing and fattening pig performance (Papaioannou et al., 2004), we conducted the study reported here, aiming at the assessment of the potential effect of Cp supplemented feed, at the inclusion rate of $2 \%$, on certain serum biochemical and hematological parameters of pigs from weaning to slaughter.

\section{Materials and methods}

\subsection{Zeolitic material}

The natural zeolite used in the present study was clinoptilolite mined from the Pentalofos Paleogene zeolite-rich tuffs of Evros County (Thrace), in northeastern Greece. The $\mathrm{Cp}$ extrusive rock was won and prepared by the company Silver and Baryte Ores Mining Co. (Athens, Greece). The granullometry of $\mathrm{Cp}$ was adjusted by crushing and screening the raw material to a size of $<1 \mathrm{~mm}(99 \%$ of the particles $<0.7 \mathrm{~mm})$. One batch of this product was used and, according to the supplier, the material's $\mathrm{NH}_{4}^{+}$cation exchange capacity (determined by the ammonium acetate method) was $1.50 \mathrm{mEq} / \mathrm{g}$, while its mineralogical and chemical composition is shown in Table 1.

\subsection{Animals and treatments}

The investigation was carried out on a farrow-tofinish pig unit with a capacity of 450 sows and an annual production of around 8500 fatteners. Forty-eight healthy

Table 1

Mineralogical and chemical composition of the zeolitic material

\begin{tabular}{|c|c|c|c|}
\hline \multicolumn{4}{|c|}{ Mineralogical composition (wt.\%) ${ }^{\mathrm{a}}$} \\
\hline Clinoptilolite & Feldspar & Micas and clays & Quartz \\
\hline $77.3 \pm 13.3$ & $12.8 \pm 6.6$ & $7.7 \pm 5.9$ & $2.2 \pm 3.9$ \\
\hline
\end{tabular}

Oxides (wt.\%) ${ }^{\mathrm{a}}$

\begin{tabular}{lrllll}
\hline $\mathrm{SiO}_{2}$ & $67.13 \pm 1.24$ & $\mathrm{Fe}_{2} \mathrm{O}_{3}$ & $0.08 \pm 0.08$ & $\mathrm{CaO}$ & $4.34 \pm 0.40$ \\
$\mathrm{TiO}_{2}$ & $0.03 \pm 0.04$ & $\mathrm{MnO}$ & $0.03 \pm 0.04$ & $\mathrm{Na}_{2} \mathrm{O}$ & $0.26 \pm 0.17$ \\
$\mathrm{Al}_{2} \mathrm{O}_{3}$ & $12.30 \pm 0.30$ & $\mathrm{MgO}$ & $1.05 \pm 0.2$ & $\mathrm{~K}_{2} \mathrm{O}$ & $0.94 \pm 0.71$
\end{tabular}

Trace elements (ppm) ${ }^{\mathrm{b}}$

\begin{tabular}{lclclclr}
\hline $\mathrm{Ag}$ & 2.6 & $\mathrm{Cs}$ & 4.7 & $\mathrm{Ni}$ & 13 & $\mathrm{Sr}$ & 1400 \\
$\mathrm{Ba}$ & 260 & $\mathrm{Cu}$ & 7.3 & $\mathrm{Nb}$ & 18 & $\mathrm{Ta}$ & 19 \\
$\mathrm{Bi}$ & 5.9 & $\mathrm{Ga}$ & 16 & $\mathrm{~Pb}$ & 62 & $\mathrm{~V}$ & 22 \\
$\mathrm{Co}$ & $<20$ & $\mathrm{Ge}$ & 2.9 & $\mathrm{Rb}$ & 110 & $\mathrm{~W}$ & 25 \\
$\mathrm{Cr}$ & 10 & $\mathrm{La}$ & 32 & $\mathrm{Sn}$ & 3.6 & $\mathrm{Y}$ & 21 \\
$\mathrm{Ce}$ & 52 & & & & & $\mathrm{Zn}$ & 41 \\
\hline
\end{tabular}

${ }^{a}$ Data obtained by Professors Yannakopoulos A. and KassoliFournaraki A. (EU funded research under Brite-Euram project no. BRE2-CT94-0954: "Development of industrial and environmental uses of European natural zeolites") and embodied in the material's registration file by Silver and Baryte Ores Mining Co. Mineralogical composition was determined by means of X-ray powder diffraction analysis using a Philips diffractometer, Ni filtered CuKa radiation. Major oxides were determined from polished thin sections using a Jeol JSM-840 scanning electron microscope equipped with a LINK-An 10000 microanalyzer.

${ }^{\mathrm{b}}$ Data obtained by Silver and Baryte Ores Mining Co. Trace element content of a representative sample of the material used in the studies, determined by means of atomic absorption spectroscopy. 
piglets, originating from sows in their 2nd to 4th parity, were individually weighed, ear-tagged and distributed according to bodyweight and sex in two experimental groups, depending on the inclusion or not of $\mathrm{Cp}$ in their feed, as follows:

$C p-$ group (12 females and 12 males): basic on-farm mixed feed;

$C p+\operatorname{group}$ (12 females and 12 males): basic on-farm mixed feed containing $\mathrm{Cp}$ at the inclusion rate of $2 \%$.

All piglets were of the same genetic background [(Large White $\times$ Landrace $) \times$ Belgian Landrace $]$ and had received creep feed free of any antimicrobial or performance enhancer during lactation.

\subsection{Management and hygiene of the animals}

The average ages for all participating pigs were $25( \pm 3)$ days at weaning and $161( \pm 3)$ days at slaughter, thus the study lasted for a period of 136 days. At weaning, they were moved from the raised pens of the farrowing house to the flat-deck unit, where they were randomly allocated to 4 pens, each comprising of 6 male and 6 female piglets, originating from different litters [in this way each experimental group consisted of 2 replicates (pens)]. The body weight of the piglets at weaning averaged $6.39 \mathrm{~kg}$ and was not significantly different $(P>0.05)$ among the experimental groups, as well as among sex and pen distributions. On $71( \pm 3)$ days of age the participating animals were moved from the flat-deck unit to the fattening accommodations, where they remained during the growing period $[71( \pm 3)-112( \pm 3)$ days of age] and the fattening one $[113( \pm 3)-161( \pm 3)$ days of age], using the same pen design, as it was initially set. The animals had no access to pasture or bedding materials. Prior to each allocation, the designated pens were thoroughly cleaned and disinfected.

Following the standard management policy of the farm, all piglets were intramuscularly injected with $200 \mathrm{mg}$ iron dextran (Iron dextran, Veterin) on the 2nd day of age. Accordingly, and based on the previous disease history of the farm, all pigs were fully vaccinated against Mycoplasma hyopneumoniae (on the 7th day of age and 15 days later), Aujeszky's disease and swine influenza [on $90( \pm 3)$ days of age and a booster shot on $120( \pm 3)$ days of age].

The experimental animals were daily monitored throughout the observation period. Any disease problems were recorded, along with the individual injectable treatments that were applied to control them. Special attention was paid for possible adverse or side effects noticed in the $\mathrm{Cp}+$ group due to the consumption of $\mathrm{Cp}$.

Management of the animals and data recording during the study were carried out under the Good Clinical Practice for the Conduct of Clinical Trials for Veterinary Medicinal Products (GCPV) guidelines (European Agency for the Evaluation of Medicinal Products, 2000).

\subsection{Feeding of the animals}

Feed and water were offered ad libitum throughout the study period. The feeds were typical maize-soybean weaning (starter and follow-on), growing and fattening rations, depending on the age of the pigs. The formulation of the basal diets used is given in Table 2. A proximate analysis and an energy determination of adequate basal feed samples were conducted in order to confirm feed composition throughout the study. The basic specifications are also shown in Table 2. The diets were also fortified with vitamins and trace elements to meet, or exceed NRC (1998) standards. The pigs of Cp+ group consumed the basal diets in which the experimental material replaced an equal quantity of barley.

In order to assess the ability of the farm's feed mill to mix the necessary ingredients efficiently, samples of each type of final feed (with and without $\mathrm{Cp}$ ) were collected and forwarded to the laboratory of Veterin S.A. (Aspropyrgos, Athens) for the determination of $\mathrm{Cp}$ inclusion rate. The results were within the analytical limits of the laboratory method used, verifying the efficient feed mixing procedure.

Mycotoxicological analysis of the used final feeds was considered necessary, since $\mathrm{Cp}$ has been shown to sequester mycotoxins such as aflatoxin $\mathrm{B}_{1}$. Reduced mycotoxin absorption from the gastrointestinal tract has been shown to ameliorate its adverse effects on serum clinical chemistry of growing pigs (Scell et al., 1993) and broilers (Oguz et al., 2000). Representative feed samples were collected on a monthly basis and forwarded to BIOMIN Laboratories (BIOMIN Gesunde Tierernahrung International Gmbh, Herzogenburg, Austria) for the determination of aflatoxin $\mathrm{B}_{1}$ concentration. The results were negative, since the estimated aflatoxin level of the submitted samples was below $4.5 \mu \mathrm{g} \mathrm{kg}^{-1}$, which represented the analytical detection limit of the HPLC method used.

\subsection{Evaluation of performance parameters}

After the initial weighing at weaning, the experimental animals were further weighed on the $70( \pm 3)$, $112( \pm 3)$ and $161( \pm 3)$ days of age (end of weaning, 
Table 2

Composition (percentage of feed ingredients) and specifications of the basal diets used in the study

\begin{tabular}{|c|c|c|c|c|}
\hline \multirow[t]{2}{*}{ Type of feed } & \multicolumn{2}{|l|}{ Weaning } & \multirow[t]{2}{*}{ Growing } & \multirow[t]{2}{*}{ Fattening } \\
\hline & Starter & Follow-on & & \\
\hline $\begin{array}{l}\text { Age of } \\
\text { pigs (days) }\end{array}$ & $\begin{array}{l}25( \pm 3)- \\
42( \pm 3)\end{array}$ & $\begin{array}{l}43( \pm 3)- \\
70( \pm 3)\end{array}$ & $\begin{array}{l}71( \pm 3)- \\
112( \pm 3)\end{array}$ & $\begin{array}{l}113( \pm 3)- \\
161( \pm 3)\end{array}$ \\
\hline Maize & 53.2 & 54.2 & 43.5 & 38.5 \\
\hline Barley & 9 & 10 & 20.5 & 22 \\
\hline Soybean meal & 16 & 16 & 19 & 19 \\
\hline Fish meal & 7.5 & 7.5 & 5 & 2.5 \\
\hline Wheat bran & - & - & 6 & 12 \\
\hline Fat (animal) & - & - & 2.5 & 2.5 \\
\hline Milk, dried ${ }^{\mathrm{a}}$ & 10 & 8 & - & - \\
\hline $\begin{array}{l}\text { Dicalcium } \\
\text { phosphate }\end{array}$ & 2 & 2 & 1.2 & 1.2 \\
\hline $\begin{array}{l}\text { Limestone } \\
\text { ground }\end{array}$ & 1 & 1 & 1 & 1 \\
\hline Iodized salt & 0.3 & 0.4 & 0.4 & 0.4 \\
\hline L-lysine-HCl & 0.4 & 0.3 & 0.3 & 0.3 \\
\hline Choline chloride & 0.2 & 0.2 & 0.2 & 0.2 \\
\hline Vitamin premix ${ }^{\mathrm{b}}$ & 0.2 & 0.2 & 0.2 & 0.2 \\
\hline $\begin{array}{l}\text { Trace elements } \\
\text { premix }^{c}\end{array}$ & 0.2 & 0.2 & 0.2 & 0.2 \\
\hline Total & 100 & 100 & 100 & 100 \\
\hline $\begin{array}{l}\text { Digestible energy } \\
\left(\mathrm{MJ} \mathrm{kg}^{-1}\right)\end{array}$ & 13.48 & 13.38 & 13.31 & 13.11 \\
\hline $\begin{array}{l}\text { Crude } \\
\text { protein }(\%)\end{array}$ & 20.8 & 20.6 & 19.2 & 18.1 \\
\hline Calcium (\%) & 0.91 & 0.85 & 0.82 & 0.76 \\
\hline Phosphorus (\%) & 0.75 & 0.72 & 0.67 & 0.62 \\
\hline Lysine (\%) & 1.48 & 1.23 & 1.03 & 0.85 \\
\hline
\end{tabular}

a Supplemented with fat (crude content 20\%).

b Provided the following per $\mathrm{kg}$ of diet: vitamin A 15,000 IU; vitamin $\mathrm{D}_{3} 2000 \mathrm{IU}$; vitamin E $30 \mathrm{mg}$; vitamin $\mathrm{K}_{3} 3 \mathrm{mg}$; vitamin $\mathrm{B}_{1}$ $2.5 \mathrm{mg}$; vitamin $\mathrm{B}_{2} 4 \mathrm{mg}$; vitamin $\mathrm{B}_{6} 3.5 \mathrm{mg}$; vitamin $\mathrm{B}_{12} 30 \mu \mathrm{g}$; biotin $30 \mu \mathrm{g}$; folic acid $0.8 \mathrm{mg}$; niacin $24 \mathrm{mg}$; pantothenic acid $16 \mathrm{mg}$; vitamin C $20 \mathrm{mg}$.

${ }^{c}$ Provided the following per kg of diet: Fe $100 \mathrm{mg}$; Zn $100 \mathrm{mg}$; Mn 40 mg; Cu 20 mg; Co 0.2 mg; I 0.6 mg; Se 0.2 mg; Mg 25 mg.

growing and fattening periods respectively) and their average daily gain was determined over the respective periods. Feed consumption per pen was also recorded over the same periods and the average daily gain (ADG) and average daily feed intake (ADFI) on pen basis were calculated by dividing total pen weight gain and total pen feed consumption by the number of animal days. The feed conversion ratio (FCR) per pen was determined as ADFI $\mathrm{ADG}^{-1}$.

\subsection{Sample collection protocol - methods of analysis}

Blood samples were collected on 25( \pm 3$)$ day of age (day of weaning), on the $70( \pm 3)$ day of age (end of weaning period), on 112( \pm 3 ) day of age (end of growing period) and on $161( \pm 3)$ day of age (end of fattening period). Sample collection was performed between 09:00 and 11:00 a.m. by jugular venipuncture and separated in two aliquots, one in plain glass tubes for serum biochemistry and one in plastic $2 \mathrm{ml}$ disodium EDTA $\left(1 \mathrm{mg} \mathrm{ml}^{-1}\right)$ tubes for hematology. Weaners were restraint in dorsal recumbency with their fore limps drawn back along the body, while the older pigs were restrained by snaring the upper jaw. At weaning, a 20-gauge, $45 \mathrm{~mm}$ long needle was used for venipuncture, while at the ensuing blood samplings a $60 \mathrm{~mm}$ long one was used.

Serum potassium $\left(\mathrm{K}^{+}\right)$and sodium $\left(\mathrm{Na}^{+}\right)$concentrations were determined using flame atomic emission spectrophotometry and a Sherwood 410 flame photometer. Total calcium ( $\mathrm{tCa}$ ) was determined by means of flame atomic absorption spectrophotometry, using a Perkin Elmer A Analyst 100 instrument (Perkin-Elmer Co., 1996). Inorganic phosphorus $\left(\mathrm{PO}_{4}^{2-}\right)$ was evaluated by the molybdenum blue method (Munoz et al., 1983). Serum aspartate aminotransferase (AST) activity and serum glucose, total protein, albumin, total cholesterol, urea nitrogen (urea-N), and total bilirubin concentrations, as well as hemoglobin concentration in EDTA-anticoagulated whole blood, were assayed using laboratory commercial kits (Boehringer Manheim Gmbh, Germany) and the standard procedures described by the manufacturing company. A HITACHI U-2000 spectrophotometer was used. Furthermore, hematocrit (PCV) was evaluated by the microhematocrit method and leucocyte counts

Table 3

Mean \pm SD body weight (BW) and average daily gain (ADG) of 2 groups of pigs which were offered feed supplemented with $2 \%$ clinoptilolite ( $\mathrm{Cp}+$ group) or were fed the unsupplemented feed and served as controls ( $\mathrm{Cp}$ - group), from day of weaning ( $25 \pm 3$ days of age) up to the slaughter day (161 \pm 3 days of age)

\begin{tabular}{|c|c|c|}
\hline \multirow{3}{*}{$\begin{array}{l}\text { Age of pigs } \\
\text { (days) }\end{array}$} & \multirow{2}{*}{$\frac{\mathrm{Cp}+}{n=24}$} & \multirow{2}{*}{$\frac{\mathrm{Cp}-}{n=24}$} \\
\hline & & \\
\hline & mean $\pm \mathrm{SD}$ & mean $\pm \mathrm{SD}$ \\
\hline \multicolumn{3}{|l|}{ Body weight (kg) } \\
\hline $25( \pm 3)$ & $6.36 \pm 0.45$ & $6.41 \pm 0.51$ \\
\hline $70( \pm 3)$ & $24.19 \pm 2.41^{\mathrm{a}}$ & $22.86 \pm 2.15^{\mathrm{b}}$ \\
\hline $112( \pm 3)$ & $53.13 \pm 4.75^{\mathrm{a}}$ & $50.27 \pm 4.79^{b}$ \\
\hline $161( \pm 3)$ & $95.61 \pm 7.21^{\mathrm{a}}$ & $90.99 \pm 6.51^{\mathrm{b}}$ \\
\hline \multicolumn{3}{|c|}{ Average daily gain $(\mathrm{kg})$} \\
\hline $25( \pm 3)-70( \pm 3)$ & $0.395 \pm 0.051^{\mathrm{a}}$ & $0.365 \pm 0.046^{\mathrm{b}}$ \\
\hline $71( \pm 3)-112( \pm 3)$ & $0.689 \pm 0.103$ & $0.652 \pm 0.086$ \\
\hline $113( \pm 3)-161( \pm 3)$ & $0.867 \pm 0.137$ & $0.831 \pm 0.122$ \\
\hline $25( \pm 3)-161( \pm 3)$ & $0.656 \pm 0.053^{\mathrm{a}}$ & $0.621 \pm 0.044^{\mathrm{b}}$ \\
\hline
\end{tabular}

${ }^{\mathrm{a}, \mathrm{b}}$ Means in the same row with different superscripts differ significantly $(P<0.05)$. 
(WBC) were determined using the UNOPETTE System $365854 / 365855$ and a Neubauer hemacytometer.

\subsection{Statistical analysis}

Statistical analysis was performed by the use of the general linear model procedure of SAS (2000; version 8.1 for Windows, 2000/site Code: 0084912001/SAS Institute Inc., Cary, NC 27513, USA). The normality of the data was tested with Kolmogorov-Smirnov test and the homogeneity of variances with Levene's test. When necessary, appropriate transformations (log) were performed. Statistical significance of the differences among the group means was calculated using Student's $t$-test.
The data on body weight were calculated on individual basis, ADG was analysed on individual and on pen basis, whereas ADFI and FCR were compared on pen basis. Furthermore, the long-term effect of $\mathrm{Cp}$ supplementation of the diet on the biochemical and hematological profiles was evaluated by the use of repeated measures analysis of variance, using a split plot design. The model included diet, time, parameter under investigation, sex and the interactions. No significant sex effect or time by diet and time by sex interactions were evident for each individual biochemical or hematological parameter $(P>0.05)$. Group means at each individual blood sample collection time were also compared by Student's $t$-test. The significance was attained if the $P$-value was $<0.05$.
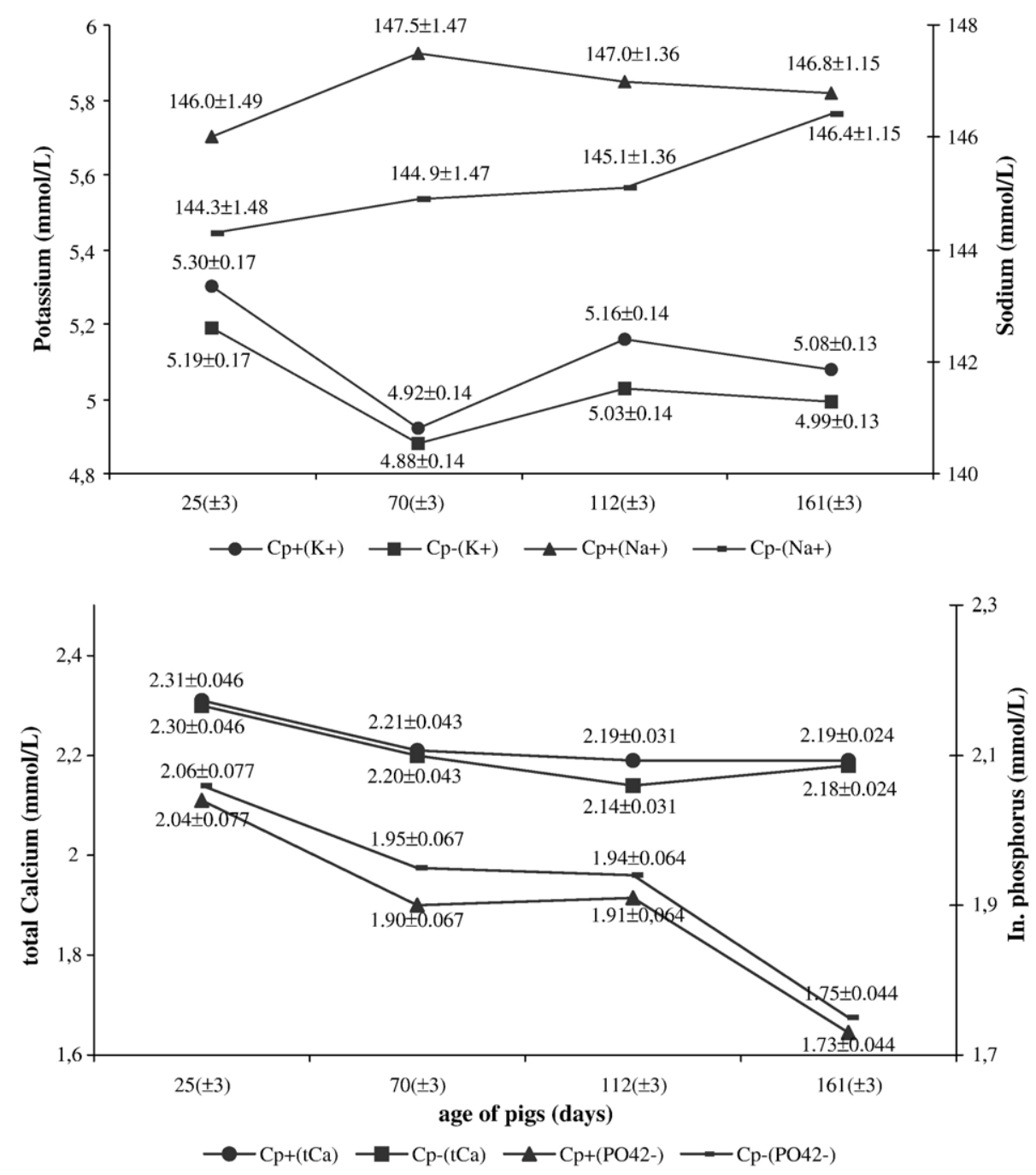

Fig. 1. Mean \pm SE serum mineral element concentrations in blood samples of 2 groups of pigs that were obtained on 4 different time points of age (weaning, end of weaning period, end of growing period, end of fattening period). $\mathrm{Cp}+$ group pigs were offered feed supplemented with $2 \%$ clinoptilolite, whereas $\mathrm{Cp}-$ group pigs were fed the unsupplemented feed and served as controls. 


\section{Results}

$\mathrm{Cp}$ was well tolerated by the animals since the consumption of the supplemented diets did not provoke any apparent adverse or side effect on them throughout the study. Three piglets ( 1 in $\mathrm{Cp}+$ group and 2 in $\mathrm{Cp}-$ group) showed transient yellowish-milky diarrhoea a few days post-weaning, which waned after a three-day treatment with parenteral enrofloxacin (Baytril, Bayer $-5 \mathrm{mg} \mathrm{kg}^{-1}$ body weight, intramuscularly, SID), without affecting their overall condition.

Table 3 provides the results obtained from the evaluation of the performance parameters estimated on individual basis. $\mathrm{Cp}$-enriched diets had a favorable effect on the animals' body weight resulting in heavier pigs $(P<0.05)$ in all weighings after the initial one. Furthermore, when estimated for the weaning period and for the whole monitoring period, ADG was found to be significantly improved by the dietary use of $\mathrm{Cp}$ $(P<0.05)$. ADG, ADFI and FCR were further calculated on a pen basis. ADFI was not affected by the dietary treatment $(P>0.05)$, although feed consumption was slightly increased in $\mathrm{Cp}+$ group $(0.680 \mathrm{~kg}$ vs. $0.665 \mathrm{~kg}, 1.771 \mathrm{~kg}$ vs. $1.739 \mathrm{~kg}, 2.662 \mathrm{~kg}$ vs. $2.605 \mathrm{~kg}$ and $1.731 \mathrm{~kg}$ vs. $1.696 \mathrm{~kg}$ in $\mathrm{Cp}+$ and $\mathrm{Cp}-$ groups during the weaning period, the growing, the fattening
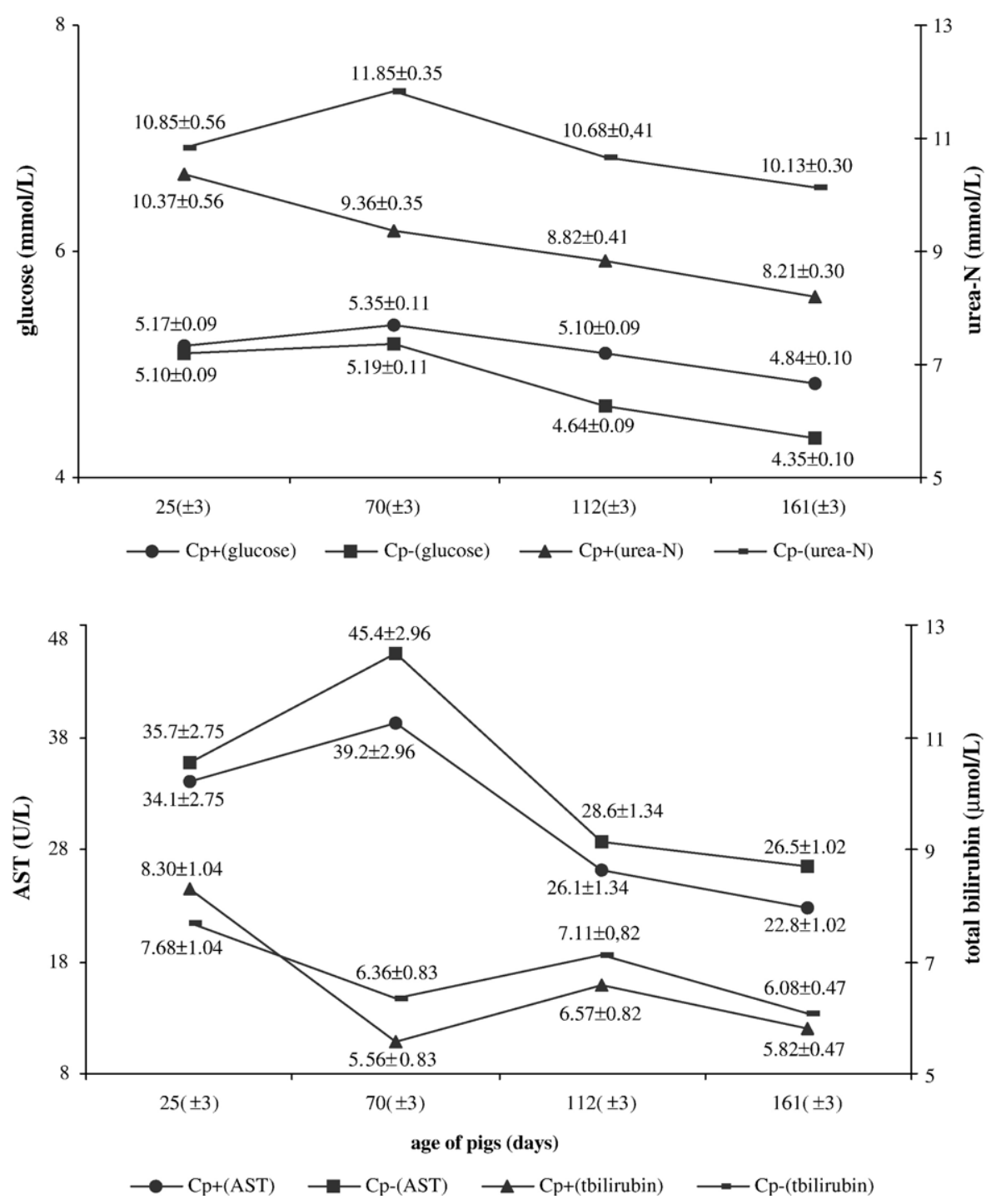

Fig. 2. Mean \pm SE serum glucose, urea-N, total bilirubin concentrations and AST activity in blood samples of 2 groups of pigs that were obtained on 4 different time points of age (weaning, end of weaning period, end of growing period, end of fattening period). Cp + group pigs were offered feed supplemented with $2 \%$ clinoptilolite, whereas $\mathrm{Cp}$-group pigs were fed the unsupplemented feed and served as controls. 
and the whole monitoring period, respectively). Adversely, FCR was found to be significantly decreased $(P<0.05)$ in the group treated with $\mathrm{Cp}$, as evidenced by the estimation during the whole monitoring period ( 2.64 vs. 2.73 in $\mathrm{Cp}+$ and $\mathrm{Cp}-$ groups, respectively).

Changes in serum mineral element concentrations of $\mathrm{Cp}+$ and $\mathrm{Cp}-$ animals throughout the study are presented in Fig. 1. On a long-term basis, serum mineral element concentrations $\left(\mathrm{K}^{+}, \mathrm{Na}^{+}, \mathrm{tCa}\right.$ and $\left.\mathrm{PO}_{4}^{2-}\right)$ were not significantly affected by feeding treatment $(P>0.05)$. Serum $\mathrm{K}^{+}$, $\mathrm{tCa}$ and $\mathrm{PO}_{4}^{2-}$ concentrations oscillated significantly with advancing age. In both treatment groups, the lowest mean serum $\mathrm{K}^{+}$concentration was determined at the end of weaning period and the highest mean serum $\mathrm{K}^{+}, \mathrm{tCa}$ and $\mathrm{PO}_{4}^{2-}$ concentrations were determined at the first blood sample collection performed on the day of weaning $(P<0.05)$. Throughout the study, serum mineral element concentrations were determined within the reference ranges (Kaneko et al., 1997), although low serum P concentrations were recorded at the last blood sampling, independently of the diet consumed by the animals.

Figs. 2 and 3 summarize the results relating to the remaining serum biochemical parameters taken into consideration in the present study. All values of the estimated AST activity and glucose, urea-N, total bilirubin, total protein, albumin, and cholesterol concentrations
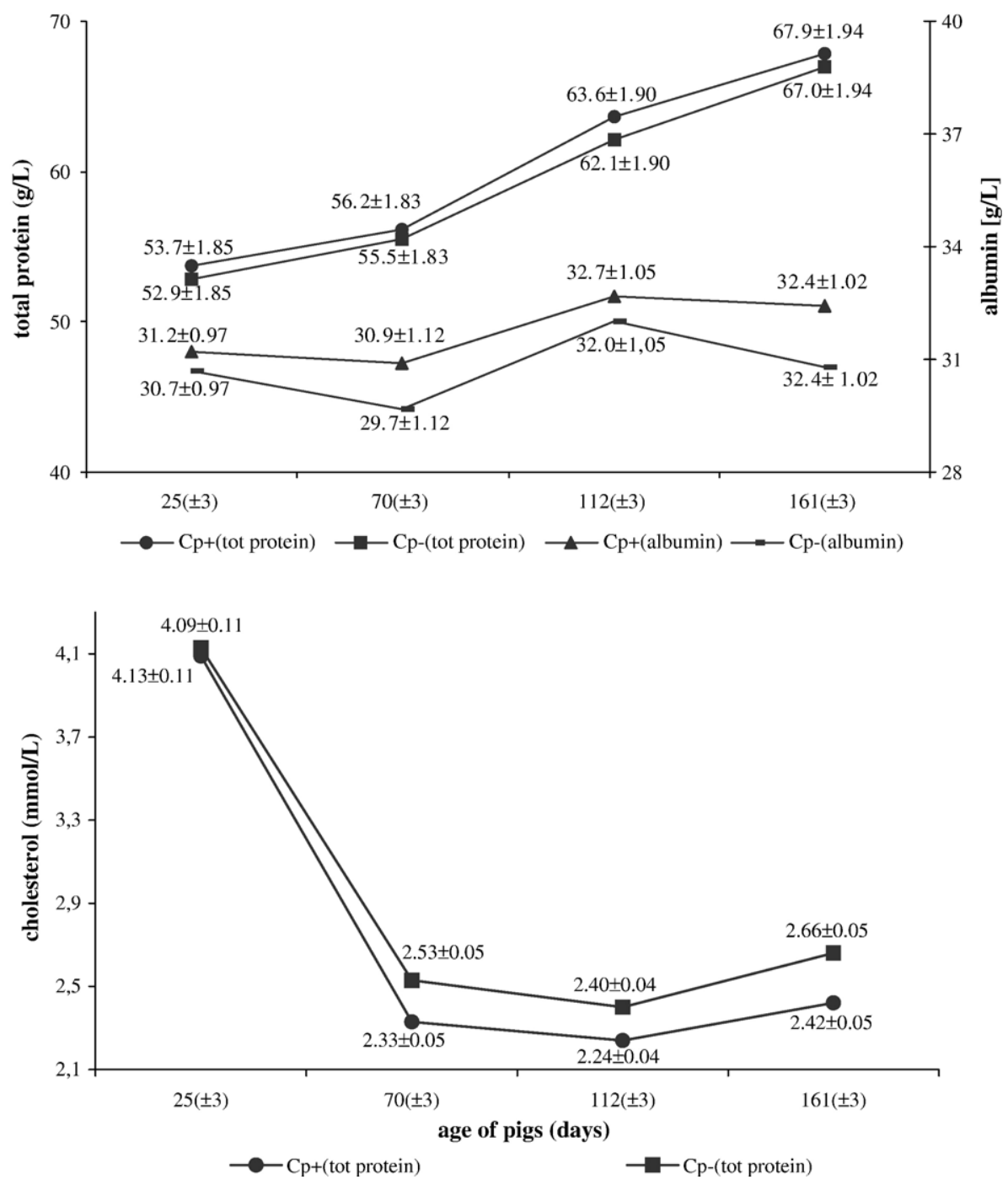

Fig. 3. Mean \pm SE serum total protein, albumin and cholesterol concentrations in blood samples of 2 groups of pigs that were obtained on 4 different time points of age (weaning, end of weaning period, end of growing period, end of fattening period). $\mathrm{Cp}+$ group pigs were offered feed supplemented with $2 \%$ clinoptilolite, whereas $\mathrm{Cp}-$ group pigs were fed the unsupplemented feed and served as controls. 

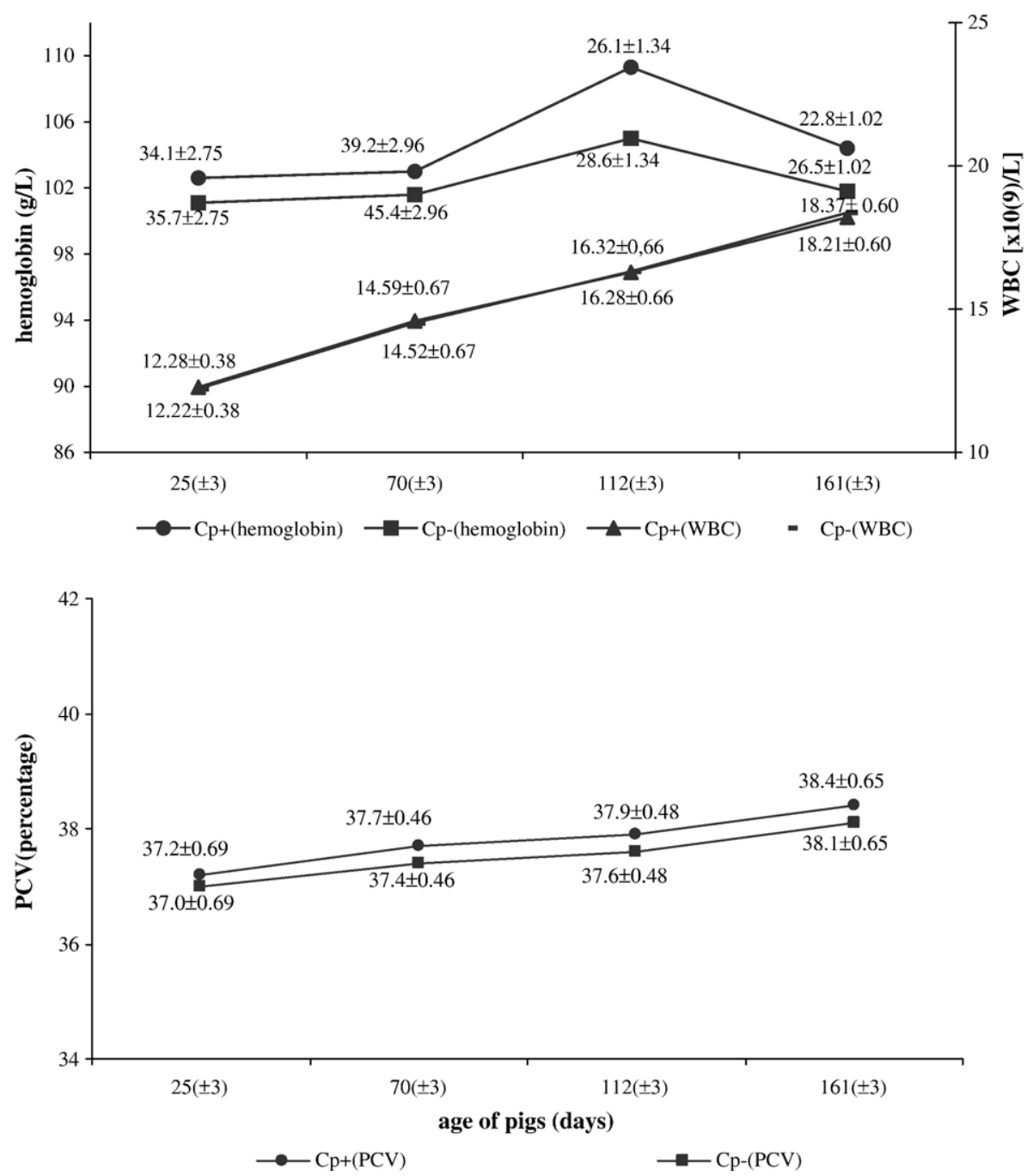

Fig. 4. Mean \pm SE blood hemoglobin concentration, leukocyte count (WBC) and hematocrit (PCV) in blood samples of 2 groups of pigs that were obtained on 4 different time points of age (weaning, end of weaning period, end of growing period, end of fattening period). Cp + group pigs were offered feed supplemented with $2 \%$ clinoptilolite, whereas $\mathrm{Cp}-$ group pigs were fed the unsupplemented feed and served as controls.

remained within the reference ranges during the studying period (Friendship et al., 1984, Gresham, 1994, Kaneko et al., 1997). Total protein, albumin and total bilirubin concentrations were not influenced by the $\mathrm{Cp}$ administration $(P>0.05)$. Adversely, $\mathrm{Cp}$ decreasing effect on AST activity was significant $(P<0.05)$, but this was evident only at the last blood sampling. Differences also emerged between the treatment groups in second to fourth blood sample collection, as regards urea-N $(P<0.001,<0.01$ and $\leq 0.001$, respectively $)$ and cholesterol concentrations $(P<0.05)$, since $\mathrm{Cp}+$ animals demonstrated significantly lower mean values than the controls. Furthermore, the consumption of the $\mathrm{Cp}$-enriched diet resulted in a higher glucose concentra- tion $(P \leq 0.001)$ at third and fourth blood samplings performed at the end of the growing and the fattening period, respectively. Repeated measures of analysis procedures also revealed a significant time effect, in both treatment groups. Total protein concentration gradually increased over time, whereas glucose and urea-N concentrations and AST activity significantly decreased from the second blood sample collection time onwards $(P<0.001)$ and total bilirubin and albumin concentrations showed considerable oscillations over time $(P<0.05)$. Within each group, the highest and the lowest mean cholesterol concentrations were found at the first and at the third blood sampling, respectively $(P<0.01)$. 
Data concerning the hematological parameters evaluated in the study are shown in Fig. 4. The dietary use of $\mathrm{Cp}$ had no effect on PCV, WBC and hemoglobin concentration $(P>0.05)$. In all cases, the estimated parameters were within the reference ranges summarized by Jain (1993). In both treatment groups, WBC demonstrated a marked increase over the studying period $(P<0.001)$, while the highest mean hemoglobin concentrations were determined at the third blood sample collection time $(P<0.05)$.

\section{Discussion}

Dietary use of zeolites has been reported to lead to contradictory results relating to their effect on performance of growing and fattening pigs (Pearson et al., 1985; Pond et al., 1988; Poulsen and Oksbjerg, 1995; Yannakopoulos et al., 2000; Papaioannou et al., 2004). The particle size of the zeolitic material, crystallite size and the degree of aggregation, as well as the porosity of individual particles determine the access of ingesta fluids to the zeolite surface during passage across the gastrointestinal tract and strongly affect its ion exchange, adsorption and catalytic properties. Thus, the type of zeolitic material, its purity and surface activity, the supplementation level used and the composition of the diet are all decisive for the extend to which any effect of the dietary use of these additives should be expected. Our results concerning body weight gains confirm previous reports where a similar experimental setting was used (Papaioannou et al 2004) or the clinoptilolite-rich tuffs had a Cp purity of $90 \%$ (Pond et al., 1988) and 77\% (Yannakopoulos et al., 2000) and were fed at the supplementation level of $2 \%$ and $6 \%$, respectively. The participating pigs fed with the $\mathrm{Cp}$-diet demonstrated a higher growth rate during the weaning stage and from weaning to slaughter. This response declined with advancing age, in agreement with the results reported by other researchers (Coffey and Pilkington, 1989; Papaioannou et al., 2004). The slight increase in ADFI observed in $\mathrm{Cp}+$ group can be ascribed to the increased bulk of the $\mathrm{Cp}$-enriched diet and to the animals' compensation for the energy diluting effect of $\mathrm{Cp}$ addition. The dietary $\mathrm{Cp}$ remains almost intact during its transit along the gastrointestinal tract and its digestibility is considered to be nil. Indeed, by extracting the inclusion rate of $\mathrm{Cp}(2 \%)$, the estimated ADFI values are almost even among the experimental groups of the study, while the difference in FCR determined for the whole monitoring period is even more pronounced. In general, the growth promoting effect of $\mathrm{Cp}$ and other zeolites or clays with more or less common physicochemical properties are attributed to a number of mechanisms which involve the binding and/ or removal of noxious compounds derived through microbial activity (i.e. ammonia and $p$-cresol), the retardation of digesta passage rate through the intestines and the favoring of feed components hydrolysis through an enzyme activity enhancement (Shurson et al., 1984; Pond et al., 1988; Cabezas et al., 1991; Olver, 1997; Parisini et al, 1999).

One of the major concerns arising by the dietary use of zeolites is their potential interaction with the dietary ingredients, such as minerals, due to their non-specific adsorption property and their ion-exchange capacity. From this point of view, valuable conclusions have been drawn by comparative studies on different animal models. A $20 \%$ increase of serum $\mathrm{K}$ has been reported to occur in mice that were fed with a $\mathrm{Cp}$-enriched diet (Martin-Kleiner et al., 2001). This finding was attributed to the liberated $\mathrm{Cp}$ constitutive $\mathrm{K}^{+}$in the small intestinal tract because of the ionic exchange for ammonium, but it is worth noting that $\mathrm{Cp}$-rich tuff was of $85 \%$ purity and was used at the supplementation level of $25 \%$. In contradiction, in experiments conducted in growing lambs (Pond et al., 1984), growing pigs (Pond et al., 1989) and sows (Papaioannou et al., 2002) it has been reported that $\mathrm{Na}$ and $\mathrm{K}$ concentrations in plasma or body tissues were not altered by the dietary use of $\mathrm{Cp}$ at the inclusion level of 2 or $3 \%$. The results of the present study are supportive to these reports, since no significant differences were noticed concerning serum $\mathrm{Na}$ and $\mathrm{K}$ concentrations among the experimental groups. Similarly, the supplementation of the diets with $\mathrm{Cp}$ did not result in any alteration in serum $\mathrm{Ca}$ and $\mathrm{P}$ concentrations, in agreement with previously reported observations in growing pigs (Vrzgula and Bartko, 1984; Yannakopoulos et al., 2000), broilers (Dwyer et al., 1997) and dairy cows (Katsoulos et al., 2005). It is worth noting that the reducing effect of sodium zeolite $\mathrm{A}$ on serum $\mathrm{P}$ concentration, as it has been demonstrated in other studies (Shurson et al., 1984; Ward et al., 1991), was attributed to the formation of insoluble phosphates after the interference of $\mathrm{P}$ with the $\mathrm{Al}$ ions removed from the degraded zeolitic material. Zeolites' stability in acid solutions is mainly controlled by the $\mathrm{Si} / \mathrm{Al}$ ratio of the structure. $\mathrm{Cp}$ is considered to remain stable in the acidic environment of the stomach and duodenum (clinoptilolite $\mathrm{Si} / \mathrm{Al}$ ratio around 5 vs. sodium zeolite $\mathrm{A} \mathrm{Si} / \mathrm{Al}$ ratio of 1), without undergoing degradation, and thus affecting $\mathrm{P}$ availability.

The results of the present study confirmed the decreasing effect of the $\mathrm{Cp}$-enriched diet on blood urea-N concentration of growing pigs (Pond and Lee, 
1984). Cp exerts a high affinity for ammonium ions produced by the deamination of dietary proteins during the digestive process and its ability to reduce the portaland anterior vena cava-blood ammonia concentration has been demonstrated by studies in rats (Pond et al., 1981) and growing pigs (Shurson et al., 1984), respectively. Urea synthesis provides a mean for excretion of ammonium and thus, a decreasing effect on urea synthesis due to the respective reduction of the amount of this toxic compound reaching the liver for detoxification, could be expected. Besides, Cp effect on the elimination of ammonium derived from the bacterial degradation of the recycled urea in the gastrointestinal tract may result in a considerable enteric loss of urea and should also be considered.

Serum urea-N concentration can also be depressed in response of a severe hepatic insufficiency. However, the evaluation of specific biochemical indicators did not manifest any evidence of liver dysfunction in the pigs supplied with $\mathrm{Cp}$. Serum total bilirubin concentration and AST activity were within normal limits, along with the lack of any effect on serum total protein and albumin concentrations. Likewise, Vrzgula and Bartko (1984) found no effect of a Cptreated diet (Cp purity of $40-60 \%$, supplementation level $5 \%$ ) on serum bilirubin concentration, AST and ALT activity in growing pigs. Similarly, the results obtained by Martin-Kleiner et al. (2001) showed that the ingestion of a much more purified Cp-rich tuff, included in the diet at the rate of 12.5 or $25 \%$, was not associated with changes in indicators of liver and kidney function in mice. Nevertheless, the decreasing effect of Cp on AST activity, as shown in our study at the last blood sampling (slaughtering age), cannot be readily explained.

Serum glucose concentration was elevated by the supplemental $\mathrm{Cp}$ in both the end of the growing and the end of the fattening periods. Nestorov (1984) reported that the use of a Cp-rich tuff with a purity of $65 \%$ at the inclusion rate of $4 \%$ in the diet of growing pigs resulted in an increase of the mesenteric blood glucose level. Additionally, the same author stated that the electron microscopic analysis of the small intestine revealed a pronounced development of Golgi's zone in the epithelial cells, together with a well-expressed pinocytosis activity. These changes can be related to an increased absorption of nutrients, also reflected to the improvement of the performance traits and to the increase of an "energetic" parameter, such as serum glucose concentration, as demonstrated in our study. However the absence of the same effect at the end of the weaning stage is somewhat peculiar. A possible explanation could lie on the gradual improvement of the utilization of the dietary complex carbohydrates with advancing age, due to the maturation of the proper enzymatic systems of the duodenal mucosa and the pancreas (Pond and Houpt, 1978).

In both the treatment groups, serum cholesterol level was higher at the first blood sampling compared to the ensuing ones. This was an expected finding associated with milk diets' increasing effect on serum cholesterol levels (Doxey, 1983, p. 71). Cp ingestion also resulted in a remarkable decrease of serum cholesterol concentration in all blood samplings performed after the initial one. The speculations beyond this response could include alterations in the dietary protein digestibility and in the absorption rate of the dietary cholesterol, as well as changes in thyroid function or bile acids homeostasis. The hypercholesterolemic effect of dietary protein restriction in growing pigs has been demonstrated (Pond et al., 1986). On the other hand, natural zeolites have been proven to promote the apparent digestibility of the dietary protein (Han et al., 1976) and to increase the $\mathrm{N}$ retention coefficient (Ly et al., 1996; Monetti et al., 1996) in pigs. However, the hypocholesterolemic effect of a potential improvement in the dietary protein metabolism in $\mathrm{Cp}+$ group cannot be confirmed, since respective responses in serum total protein and albumin concentrations were not detected. Cholesterol balance throughout the body is maintained by regulatory mechanisms among which, the rate of intestinal absorption of the dietary cholesterol is not considered to be of major importance (Beynen, 1990).

Based on the combined findings of our study, the inverse pattern of serum glucose and cholesterol alterations in response to $\mathrm{Cp}$ ingestion may also indicates an increase in thyroid activity. The potential effect of $\mathrm{Cp}$ on thyroid function needs further research in order to be precluded.

The obstruction of bile acids' enterohepatic circulation may be followed by enhancement of their formation from cholesterol in the liver and a drop in serum cholesterol level (Voet and Voet, 1995). It has been shown that the elimination of neutral steroids and bile acids in the feces of pigs induced by either partial ileal bypass (Schouten et al., 1985) or by the enhanced bacterial bile salt hydrolase activity (De Smet et al., 1998), exerts a pronounced hypocholesterolemic effect. In the same direction, other studies have demonstrated the ability of a purified zeolite to bind the bile acids in the intestinal tract (Rodriguez-Fuentes et al., 1997) thus, preventing their absorption. This mechanism stands as the most likely explanatory one for the hypocholesterolemic effect of $\mathrm{Cp}$ ingestion, 
although the determination of fecal bile acids content in our study would afford more firmly established conclusions.

Although the affinity of $\mathrm{Cp}$ for $\mathrm{Fe}^{2+}$ or ${ }^{3+}$ is not as high as in the case of other ions (Mumpton, 1999), a potential long-term effect on erythropoiesis cannot be precluded. According to our results, the supplementation of the diets with $\mathrm{Cp}$ did not provoke any unfavorable effect on erythropoiesis. PCV and hemoglobin concentration of the $\mathrm{Cp}$-treated pigs were comparable to the controls throughout the observation period. Similar results have been obtained in growing pigs (Vrzgula and Bartko, 1984) and mice (MartinKleiner et al., 2001). However, a rise of the hemoglobin concentration in the blood, as well as of the leucocyte and lymphocyte counts of weaning pigs fed a Cp-enriched diet has been reported (Petkova et al., 1982). Accordingly, leucocytosis due to the increase of the lymphocyte count was noticed in similarly fed mice (Martin-Kleiner et al., 2001). The latter was combined with macroscopical evidence of intestinal hyperemia and attributed to the intestinal irritation and inflammation by the zeolitic particles. Although the particle size of the zeolitic material used in the present study was comparable to the respective ones used in the aforementioned studies, no significant effect on WBC of the treated pigs was noticed, nor the slaughterhouse intestinal tract examination revealed any apparent sign of irritation. These findings were further supported by the lack of any alteration response to $\mathrm{Cp}$ ingestion on serum total protein concentration, which would have been expected to be substantially increased if an inflammatory process was provoked by $\mathrm{Cp}$. WBC was progressively increased with advancing age in the experimental animals of both treatments. Age effect on WBC has been also described by Pond and Houpt (1978).

\section{Conclusion}

It is concluded that the supplementation of diets with $\mathrm{Cp}$ of similar physical and chemical properties as that used in the present study, at the inclusion rate of $2 \%$ and in a long-term basis, is not associated with any adverse effect on growing and fattening pigs' overall condition and does not provoke any undesirable effect on the evaluated serum biochemical and hematological parameters. More or less pronounced changes in serum glucose, urea- $\mathrm{N}$ and cholesterol concentrations seem to represent the endpoint of systemic effects resulted by $\mathrm{Cp}$ ingestion and do not suggest impairment of animals' health status and performance.

\section{Acknowledgements}

The study is part of a research project conducted under the licence of Veterinary County Administration of Karditsa for experimenting animals. The project was financed by Silver and Baryte Ores Mining Co. (Athens, Greece) and New Vet S.A (Athens, Greece), through the Research Committee of the Aristotle University of Thessaloniki.

\section{References}

Beynen, A.C., 1990. Farm animals as models of cholesterol metabolism. In: Pliska, V., Stranzinger, G. (Eds.), Farm Animals in Biomedical Research. Verlag Paul Parey, Hamburg and Berlin, pp. 33-42.

Cabezas, M.J., Salvador, D., Sinisterra, J.V., 1991. Stabilizationactivation of pancreatic enzymes adsorbed on to a sepiolite clay. J. Chem. Technol. Biotechnol. 52, 265-274.

Coffey, M.T., Pilkington, D.W., 1989. Effect of feeding Zeolite-A on the performance and carcass quality of swine. J. Anim. Sci. 67 (Supplement2), 36 (abstract).

Cool, W.H., Willard, J.M., 1982. Effect of clinoptilolite on swine nutrition. Nutr. Rep. Int. 26, 759-766.

De Smet, I., De Boever, P., Verstraete, W., 1998. Cholesterol lowering in pigs through enhanced bacterial bile salt hydrolase activity. Br. J. Nutr. 79, 185-194.

Doxey, D.L., 1983. Clinical Pathology and Diagnostic Procedures, 2nd ed. Baillière Tindall, London.

Dwyer, M.R., Kubena, L.F., Harvey, R.B., Mayura, K., Sarr, A.B., Buckley, S., Bailey, R.H., Phillips, T.D., 1997. Effect of inorganic adsorbents and cyclopiazonic acid in broiler chicken. Poult. Sci. $76,1141-1149$.

Enemark, J.M., Frandsen, A.M., Thilsing-Hansen, T., Jorgensen, R.J., 2003. Aspect of physiological effects of sodium zeolite: a supplementation in dry, non-pregnant dairy cows fed grass silage. Acta Vet Scand suppl. 97, 97-117.

European Agency for the Evaluation of Medicinal Products, 2000. Guideline on Good Clinical Practice - EMEA/CVMP/VICH/595/ 98 - Final. Press Office, EMEA, London, UK.

Friendship, R.M., Lumsden, J.H., McMillan, I., Wilson, M.R., 1984. Hematology and biochemistry reference values for Ontario swine. Can. J. Comp. Med. 48, 390-393.

Gerasev, A.D., Lukanina, S.N., Sviatash, G.A., Aizman, R.I., 2003a. Characteristics of the $\mathrm{K}^{+}$-ion transport in the rat intestine following the use of natural zeolites as food additives. Ross Fiziol Zh Im I M Sechenova 89, 972-981 (in Russian, with English abstract).

Gerasev, A.D., Sviatash, G.A., Lukanina, S.N., Taranov, A.G., Aizman, R.I., 2003b. Effect of natural zeolites on renal functions and water-salt metabolism in rats. Ross Fiziol Zh Im I M Sechenova 89, 879-887 (in Russian, with English abstract).

Gresham, A.C.J., 1994. Porcine clinical biochemistry. Pig J. 32, 58-67.

Han, I.K., Park, H.K., Kim, C.S., 1976. Studies on the nutritive value of zeolites. 2. Effects of zeolite rich hull mixture on the performance of growing-finishing swine. Korean J Anim Sci. 18, 225-230.

Jain, N.C., 1993. Essentials of Veterinary Hematology. Lea \& Febiger, Philadelphia, USA.

Kaneko, J.J., Harvey, J.W., Bruss, M.L., 1997. Appendixes, In: Kaneko, J.J., Harvey, J.W., Bruss, M.L. (Eds.), Clinical Biochemistry of 
Domestic Animals, 5th ed. Academic Press, San Diego, California, USA, pp. 885-905.

Kartashev, A.G., Baskurin, A.K., 1995. Changes in the blood system of white mice with long term zeolite administration. Fiziol Zh. 41, 14-19 (in Russian, with English abstract).

Katsoulos, P.D., Roubies, N., Panousis, N., Arsenos, G., Christaki, E., Karatzias, H., 2005. Effects of long-term dietary supplementation with clinoptilolite on incidence of parturient paresis and serum concentration of total calcium, phosphate, magnesium, potassium and sodium in dairy cows. Am. J. Vet. Res. 66, 2081-2085.

Ly, J., Lon-Wo, E., Castro, M., 1996. N and energy balance in pigs fed sugar cane molasses and natural zeolites from different deposits. Cuban J. Agric. Sci. 26, 131-134.

Martin-Kleiner, I., Flegar-Mestric, Z., Zadro, R., Reljak, D., Stanovic Janda, S., Stojkovic, R., Merusic, M., Redacic, M., Boranic, M., 2001. The effect of the zeolite clinoptilolite on serum chemistry and hematopoiesis in mice. Food Chem. Toxicol. 39, 717-727.

Monetti, P.G., Tassinari, M., Vignola, G., Gonzales-Valdez, J.L., 1996. Nitrogen balance and apparent digestibility coefficients of some nutrients in growing pigs fed diets containing a natural zeolite. Zootec. Nutr. Anim. 22, 159-167.

Mumpton, F.A., 1999. La roca magica: uses of natural zeolites in agriculture and industry. Proc. Natl. Acad. Sci. U.S.A. 96, 3463-3470.

Munoz, M.A., Balon, M., Fernandez, C., 1983. Direct determination of inorganic phosphorus in serum with a single reagent. Clin. Chem. $29,372-374$.

Nestorov, N., 1984. Possible applications of natural zeolites in animal husbandry. In: Pond, W.G., Mumpton, F.A. (Eds.), Zeo-Agriculture. Use of Natural Zeolites in Agriculture and Aquaculture. Westview Press Inc., Boulder, Colorado, p. 167-174.

NRC, 1998. Nutrient Requirements of Swine, 10th rev. ed. National Academy of Sciences, National Academy Press, Washington, DC, USA.

Oguz, H., Kececi, T., Birdane, Y.O., Onder, F., Kurtoglu, V., 2000. Effect of clinoptilolite on serum biochemical and hematological characters of broiler chickens during aflatoxicosis. Res. Vet. Sci. 69, 89-93.

Olver, M.D., 1997. Effect of feeding clinoptilolite (zeolite) on the performance of three strains of laying hens. Br. Poult. Sci. 38, 220-222.

Papaioannou, D.S., Kyriakis, S.C., Papasteriadis, A., Roumbies, N., Yannakopoulos, A., Alexopoulos, C., 2002. Effect of in-feed inclusion of a natural zeolite (clinoptilolite) on certain vitamin, macro and trace element concentrations in the blood, liver and kidney tissues of sows. Res. Vet. Sci. 72, 61-68.

Papaioannou, D.S., Kyriakis, C.S., Alexopoulos, C., Tzika, E.D., Polizopoulou, Z.S., Kyriakis, S.C., 2004. A field study on the effect of the dietary use of a clinoptilolite-rich tuff, alone or in combination with certain antimicrobials, on the health status and performance of weaned, growing and finishing pigs. Res. Vet. Sci. 76, 19-29.

Parisini, P., Martelli, G., Sardi, L., Escribano, F., 1999. Protein and energy retention in pigs fed diets containing sepiolite. Anim. Feed Sci. Technol. 79, 155-162.

Pearson, G., Smith, W.C., Fox, J.M., 1985. Influence of dietary zeolite on pig performance over the liveweight range $25-87 \mathrm{~kg}$. New Zealand J. Exp. Agric. 13, 151-154.

Perkin-Elmer Co, 1996. Atomic Absorption Spectroscopy, Analytical Methods.

Petkova, E., Venkov, T., Chushkov, P., Stefanov, T., Poshchakov, E., 1982. Prophylactic efficacy of Bulgarian potassium-calcium zeolite in digestion disorders in pigs. Vet. Med. Nauki. 19, 45-51 (in Bulgarian, with English abstract).

Pond, W.G., Houpt, K.A., 1978. The Biology of the Pig. Cornell University Press, Ithaca, New York, USA, p. 282.
Pond, W.G., Lee, J.T., 1984. Physiological effects of clinoptilolite and synthetic zeolite A in animals. In: Pond, W.G., Mumpton, F.A. (Eds.), Zeo-Agriculture. Use of Natural Zeolites in Agriculture and Aquaculture. Westview Press Inc., Boulder, Colorado, pp. 129-145.

Pond, W.G., Yen, J.T., Hill, D.A., 1981. Decreased absorption of orally administered ammonia by clinoptilolite in rats. Proc. Soc. Exp. Biol. Med. 166, 369-373.

Pond, W.G., Laurent, S.M., Orloff, H.D., 1984. Effect of dietary clinoptilolite or zeolite Na-A on body weight gain and feed utilization of growing lambs fed urea or intact protein as a nitrogen supplement. Zeolites 4, 127-132.

Pond, W.G., Yen, J.T., Mersmann, H.J., Haschek, W.M., 1986. Comparative effects of dietary protein and cholesterol-fat content on genetically lean and obese pigs. J. Nutr. 116, 1116-1124.

Pond, W.G., Yen, J.T., Varel, V.H., 1988. Response of growing swine to dietary copper and clinoptilolite supplementation. Nutr. Rep. Int. 37, 797-803.

Pond, W.G., Yen, J.T., Crouse, J.T., 1989. Tissue mineral element content in swine fed clinoptilolite. Bull. Environ. Contam. Toxicol. 42, 735-742.

Poulsen, H.D., Oksbjerg, N., 1995. Effects of dietary inclusion of a zeolite (clinoptilolite) on performance and protein metabolism of young growing pigs. Anim. Feed Sci. Technol. 53, 297-303.

Ramu, J., Clark, K., Woode, G.N., Sarr, A.B., Phillips, T.D., 1997. Adsorbtion of cholera and heat-labile Escherichia coli enterotoxins by various adsorbents: an in vitro study. J Food Prot. 60, 358-362.

Rodriguez-Fuentes, G., Barrios, M.A., Irairoz, A., Perdomo, I., Cedre, B., 1997. Enterex: anti-diarrheic drug based on purified natural clinoptilolite. Zeolites. 19, 441-448.

SAS/STAT ${ }^{\circledR}, 2000$. User's Guide, Version 8, Volumes 1, 2 and 3. $\mathrm{SAS}^{\circledR}$ Institute Inc., Cary, NC.

Scheideler, S.E., 1993. Effects of various types of aluminosilicates and aflatoxin $\mathrm{B}_{1}$ on aflatoxin toxicity, chick performance and mineral status. Poult. Sci. 72, 282-288.

Scell, T.C., Lindemann, M.D., Kornegay, E.T., Blodgett, D.J., Doerr, J.A., 1993. Effectiveness of different types of clay for reducing the detrimental effects of aflatoxin-contaminated diets on performance and serum profiles of weanling pigs. J. Anim. Sci. 71, 1226-1231.

Schouten, J.A., Beynen, A.C., Hoitsma, H.F.W., Mulder, C., Havekes, L.M., Van Gent, C.M., 1985. Serum lipoproteins in cholesterol-fed pigs after partial ileal bypass. Lab. Anim. 19, 98-105.

Shurson, G.C., Ku, P.K., Miller, E.R., Yokohama, M.T., 1984. Effects of zeolite A or clinoptilolite in diets of growing swine. J. Anim. Sci. 59, 1536-1545.

Voet, D., Voet, J.G., 1995. Biochemistry, 2nd ed. John Wiley \& Sons Inc, New York, USA, p. 701.

Vrzgula, L., Bartko, P., 1984. Effects of clinoptilolite on weight gain and some physiological parameters of swine. In: Pond, W.G., Mumpton, F.A. (Eds.), Zeo-Agriculture. Use of Natural Zeolites in Agriculture and Aquaculture. Westview Press Inc., Boulder, Colorado, pp. 161-166.

Ward, T.L., Watkins, K.L., Southern, L.L., Hoyt, P.G., French, D.D., 1991. Interactive effects of sodium zeolite-A and copper in growing swine: growth, and bone and tissue mineral concentrations. J. Anim. Sci. 69, 726-733.

Yannakopoulos, A., Terveni-Gousi, A., Kassoli-Fournaraki, A., Tsirambides, A., Michailidis, K., Filippidis, A., Lutat, U., 2000. Effects of dietary clinoptilolite-rich tuff on the performance of growing-finishing pigs. In: Coela, C., Mumpton, F.A. (Eds.), Natural Zeolites for the Third Millenium. De Frede Editore, Napoli, Italy, pp. 471-481. 